\title{
Agrotechnological assessment of the application of biological preparations and micronutrient fertilizers in spring wheat
}

\author{
Zhanna Minchenko, and Alexander Bashkatov \\ FSBSI «Kursk Federal Agricultural Research Center»70b, Karl Marx St., Kursk, 305021, Russia
}

\begin{abstract}
The results of the research on the assessment of the effectiveness of the application of biological fertilizer Humistim and micronutrient fertilizers MicroFeed Complex and MicroFeed Extra Phosphorus in the cultivation of spring wheat under the conditions of Kursk Region are presented. As a result of the research, it was found that the preparations (Humistim, MicroFeed Complex and MicroFeed Extra Phosphorus) contributed to the better growth and development of spring wheat, reduced the development of leaf-stem diseases, increased the yield and quality of spring wheat grain. Thus, when treating seeds $(51 / t)$ and crops in the tillering phase and early booting $(5 \mathrm{l} / \mathrm{ha}$ ) with Humistim fertilizer, the development of septoria was $16.4 \%$, biological efficiency was $36.4 \%$, the yield of spring wheat increased by $0.55 \mathrm{t} / \mathrm{ha}$, gluten content in the grain by $2.1 \%$, compared with the control variant. When using micronutrient fertilizers MicroFeed Complex and MicroFeed Extra Phosphorus at a rate of $1.51 / t$ for seed treatment and 1.5 1/ha for crop treatment in the tillering phase and early booting the biological efficiency was slightly lower and amounted to $-32.6-33.7 \%$, the yield of spring wheat increased by $0.52-0.53 \mathrm{t} / \mathrm{ha}$, the gluten content in the grain by 1.7-1.9\%. Calculations of economic efficiency showed that the treatment of seeds and crops of spring wheat with the biological fertilizer Humistim increased direct production costs by $825 \mathrm{rubl} . / \mathrm{ha}$, but due to the increase in yield, the cost of gross production increased by $6,600 \mathrm{rubl}$./ha, conditional net income by $5,775 \mathrm{rubl} . / \mathrm{ha}$, the cost of 1 ton of grain decreased by 511.55 rubles. The efficiency of using fertilizers with micronutrients MicroFeed Complex and MicroFeed Extra Phosphorus with similar methods of application was slightly lower: the value of conditional net income was 27,693.31-30,255.31 rubl./ha. MicroFeed Extra Phosphorus fertilizer provided a minimum increase in conditional net income 2,940 rubles/ha, which is due to its higher cost.
\end{abstract}

\section{Introduction}

One of the main tasks in the field of agriculture is to increase the level of yield and the gross grain harvest, due to the full realization of the genetically determined yield potential of cultivated varieties $[1,2,3]$. The increase in the productivity of spring wheat is largely determined by the efficiency of its growing technologies, depending on the soil and climatic conditions of the region of its cultivation and the level of agricultural intensification [4, 5]. Modern economic and environmental problems dictate the need to improve the applied technologies in the direction of their biologization and resource conservation $[6,7]$.

In recent years, the sown area of spring wheat in Kursk Region amounted to 51-100 thousand hectares, which is $4.8-9.7 \%$ of the sown area of grain crops. The average yield of spring wheat over these years ranged from 4.04 t/ha in 2018 to $5.11 \mathrm{t} / \mathrm{ha}$ in 2020 , and depended on the cultivation technology, climate, fertilization level, and other factors [8].

An increase in the production of this crop is possible only through the development of modern agricultural technologies of cultivation, which are a set of techniques for managing the production process in order to obtain the planned yield of high-quality products while ensuring environmental safety and economic efficiency $[9,10,11]$. One of these methods is the optimization of mineral nutrition, where in addition to the application of traditional mineral fertilizers, there is a need to use biological fertilizers, complex fertilizers with trace elements in chelated form, growth regulators, etc. $[12,13,14]$.

Such preparations, widely used in modern production, include: bio-fertilizer Humistim and complex micronutrient fertilizers of the MicroFeed brand.

Humistim is a complex natural, environmentally friendly biofertilizer made from biohumus, peat and extracts of medicinal plants. The preparation contains components of vermicompost in the dissolved state: humins, fulvic acids, vitamins, natural phytohormones, spores of useful soil microorganisms and micro-and macronutrients in chelated form. The preparation is an inducer of plant immunity, has adaptogenic properties, promotes anti-stress resistance of plants to diseases and adverse environmental conditions, has high chemical purity and solubility, increases productivity and product quality.

MicroFeed Complex is a universal complex liquid micronutrient fertilizer with a high content of glycerol, silicon and trace elements $(\mathrm{Mg}, \mathrm{B}, \mathrm{Cu}, \mathrm{Mn}, \mathrm{Zn})$ in an accessible chelated form. The preparation makes up for 
the missing elements of mineral nutrition in the soil and plants. It is recommended for foliar dressing during the entire growing season, as well as for the presowing seed treatment. Due to the high content of glycerin, it practices a stimulating and protective effect.

Microfeed Extra Phosphorus is a liquid micronutrient fertilizer with a high content of phosphorus, potassium, sulfur, silicon and microelements $(M g, B, C u, M n, Z n)$ in an accessible chelated form. The preparation contains natural neutral surface-active agent (zinc, glycerin, silicon), which increases the penetration of nutrients into the plant, as well as plant lipids involved in the plant cell formation. The preparation is used practically for all crops.

The purpose of the study is to determine the effectiveness of different methods of application (seed treatment, crop treatment) of biofertilizer Humistim and complex fertilizers with microelements (MicroFeed Complex, Microfeed Extra Phosphorus), as well as their influence on the yield and grain quality of spring soft wheat cultivated on chernozem soils of Kursk Region.

\section{Objects and methods}

Research on the effectiveness of various methods of application of bio-fertilizer Humistim and complex fertilizers with microelements in spring wheat of Darya variety was conducted in 2018-2020 in the field experiment of the Laboratory for the Technologies of Field Crops Cultivation and Agroecological Assessment of Lands of the FSBSI "Kursk Federal Agricultural Research Center".

The crop rotation is presented by the following crop alternation: clean fallow-winter wheat-sugar beet-spring wheat. The design of the experiment included seed treatment with bio- and trace element preparations and treatment of seeds and vegetating plants in the phases of tillering and early booting. Absolute control was a variant where treatment was not performed.

The replication of the experiment is three-fold, the placement of the variants within the plot is systematic in one tier, the size of the record plot is $100 \mathrm{~m}^{2}(2 \times 50)$. The soil of the experimental plot is a typical deep heavy loamy chernozem. The content of humus in the arable layer is $6.0 \%$, mobile phosphorus $14.5 \mathrm{mg} / 100 \mathrm{~g}$ of soil (according to Chirikov method), exchangeable potassium $11.8 \mathrm{mg} / 100 \mathrm{~g}$ of soil (according to Maslova method). The reaction of the soil medium is neutral: $\mathrm{pH}$ is 6.7 . As for the content of mobile forms of boron $0.34 \mathrm{mg} / \mathrm{kg}, 0.30$ $\mathrm{mg} / \mathrm{kg}$ of copper, $0.32 \mathrm{mg} / \mathrm{kg}$ of zinc, $4.50 \mathrm{mg}$-eq. $/ 100 \mathrm{~g}$ of magnesium, the soil of the experimental plot is classified as medium-rich.

The field work on the experimental plot was carried out in the best agronomical terms with the machines and equipment that were used under industrial conditions. The background of mineral nutrition is $\mathrm{N}_{30} \mathrm{P}_{30} \mathrm{~K}_{30}$ applied in autumn with primary tillage in all the variants of the experiment. The treatment of the spring wheat seeds with the preparations (Humistim, MicroFeed Complex and MicroFeed Extra Phosphorus) was carried out 1 day before sowing, starting with a satchel sprayer, then the seeds were dried in a shaded place. The treatment of vegetating plants of spring wheat was also carried out with a satchel sprayer in accordance with the design of the experiment. Seeds that met the requirements of the $1 \mathrm{st}$ class according to the sowing standard were used for sowing with a seeding rate of 5 million tons per hectare. The method of sowing was drill sowing. The depth of seeding was $4-5 \mathrm{~cm}$.

Harvesting of spring wheat was carried out by a selfpropelled harvester "Sampo-500", by the method of a direct harvesting. At that time the entire area of the record plot was harvested, the grain was weighed on decimal scales. The conversion of the grain was carried out in terms of $100 \%$ purity and $14 \%$ moisture content in the grain. In the grain samples of spring wheat the content of raw gluten was determined by the standard method (I. E. Kazakov, 1967), natural grain weight by the state standard (GOST-10840-76), the weight of 1000 grains by the state standard (GOST-10842-76).

The analysis of meteorological conditions in the years of the study showed that the growing season of spring wheat in 2018 was the coolest and wettest. The average daily temperature of the vegetation period (April - July) was by $0.2^{\circ} \mathrm{C}$ lower than the long-term average $\left(14.2^{\circ} \mathrm{C}\right)$, and the total precipitation was $126.7 \%$ of the norm. In 2019-2020 the weather conditions of the growing seasons turned out hotter and with less precipitation: the average temperature was by $1.8-0.7^{\circ} \mathrm{C}$ higher than the long-term average $\left(14.2^{\circ} \mathrm{C}\right)$, with the total precipitation $91.9-99.3 \%$ of the long-term average $(215.0 \mathrm{~mm})$.

\section{Results and Discussion}

As a result of the conducted research, it was established that the seed treatment and double treatment of the spring wheat with bio- and micronutrient fertilizers influenced positively position on the growth and development of plants, increased the yield and improved the qualitative indicators of spring wheat grain.

The calculation of the standing density of spring wheat by the experimental variants showed that the treatment of seeds with Humistim (5 1/t), MicroFeed Complex (1.5 1/t) and MicroFeed Extra Phosphorus $(1.5 \mathrm{l} / \mathrm{t})$ increased the field germination of seeds by 1.2-3.4\% (Table 1 ).

Table 1. Effect of biofertilizer Humistim and fertilizers of the brand MicroFeed on the field germination rate of spring wheat seeds, 2018-2020 yrs.

\begin{tabular}{|c|c|c|}
\hline Variants & $\begin{array}{c}\text { Number } \\
\text { of } \\
\text { seedlings } \\
\text { pcs/ } 1 \mathrm{~m}^{2}\end{array}$ & $\begin{array}{c}\text { Field } \\
\text { germination } \\
\text { rate, } \\
\%\end{array}$ \\
\hline 1.Control (untreated) & 476 & 95.2 \\
\hline $\begin{array}{c}\text { 2.Humistim }(5 \mathrm{l} / \mathrm{t}), \\
\text { seed treatment }\end{array}$ & 493 & 98.6 \\
\hline $\begin{array}{c}\text { 3.MicroFeed } \\
\text { Complex }(1.5 \mathrm{l} / \mathrm{t}) \\
\text { seed treatment }\end{array}$ & 486 & 97.2 \\
\hline
\end{tabular}




\begin{tabular}{|c|c|c|}
\hline $\begin{array}{c}\text { 4.Microfeed Extra } \\
\text { Phosphorus }(1.5 \mathrm{l} / \mathrm{t}) \\
\text { seed treatment }\end{array}$ & 482 & 96.4 \\
\hline LSD $_{05}$ & 8 & \\
\hline
\end{tabular}

The phytosanitary condition of spring wheat crops in the years of research was characterized by a moderate infectious background. Spring wheat crops were affected byseptoriosis (Septoria nodorum). The determination of the prevalence of this disease in spring wheat carried out in the early heading phase showed that the most severe spread of septoriosis was observed in the control variant $-25.8 \%$. (Table 2 ).

The use of the biological preparation Humistim and microelement fertilizers of the MicroFeed brand had a restraining effect on the spread of this disease. Thus, when treating seeds with Humistim at a rate of $51 / t$, the development of the disease was $20.1 \%$, biological efficiency $22.1 \%$. When treating seeds with microelement fertilizers of the MicroFeed brand at a rate of $1.5 \mathrm{l} / \mathrm{t}$, the biological efficiency was lower and amounted to: MicroFeed Complex-17.4\%, MicroFeed Extra Phosphorus-15.9\% (Table 2).

The best result for restraining leaf-stem diseases under the conditions of 2018-2020 was obtained from seed treatment and double crop treatment in the tillering and early booting phases with Humistim biofertilizer: the biological effectiveness of the biological preparation in this variant was $36.4 \%$, and when using microelement fertilizers MicroFeed 32.6-33.7\%, respectively.

Good phytosanitary condition of the crops in the variants with the use of bio-and microelement fertilizers ensured the formation of a better structure of the spring wheat yield. Thus, the treatment of seeds with the preparation Humistim at a rate of $51 / \mathrm{t}$ increased the number of productive stems by $12 \mathrm{pcs} / \mathrm{m}^{2}$, the grain content of the ear by $0.5 \mathrm{pcs}$, the weight of 1000 grains by $1.8 \mathrm{~g}$, in comparison with the control, and when treating seeds with microelement fertilizers MicroFeed Complex and MicroFeed Extra Phosphorus at a rate of $1.51 / \mathrm{t}$ by 9 $10 \mathrm{pcs} / \mathrm{m}^{2}, 0.2-0.3 \mathrm{pcs}, 1.4 \mathrm{~g}$, respectively.

Table 2. Effect of Humistim and MicroFeed fertilizers on the infectability of spring wheat plants with septoriosis, 2018-2020

\begin{tabular}{|c|c|c|}
\hline \multirow{2}{*}{ Variants } & \multicolumn{2}{|c|}{ Septoriosis } \\
\cline { 2 - 3 } & $\begin{array}{c}\text { prevalence } \\
\%\end{array}$ & $\begin{array}{c}\text { biological } \\
\text { efficiency } \\
\%\end{array}$ \\
\hline $\begin{array}{c}\text { 1. Control (untreated) } \\
\text { treatment }\end{array}$ & 25.8 & - \\
\hline $\begin{array}{c}\text { 2. Humistim (5 } 1 / \mathrm{t}), \text { seed } \\
\text { (1.5 1/t) seed treatment }\end{array}$ & 20.1 & 22.1 \\
\hline $\begin{array}{c}\text { 4. Microfeed Extra } \\
\text { Phosphorus }(1.51 / \mathrm{t}) \text { seed } \\
\text { treatment }\end{array}$ & 21.7 & 17.4 \\
\hline $\begin{array}{c}\text { 5. Humistim }(5 \mathrm{l} / \mathrm{t}) \text { of } \\
\text { seed treatment }+(1.5 \mathrm{l} / \mathrm{ha}) \\
\text { crop spraying in the }\end{array}$ & 16.4 & 36.4 \\
\hline
\end{tabular}

\begin{tabular}{|c|c|c|}
\hline $\begin{array}{c}\text { tillering and early booting } \\
\text { phases }\end{array}$ & & \\
\hline $\begin{array}{c}6 . \text { Microfeed Complex } \\
(1.5 \mathrm{l} / \mathrm{t}) \text { seed treatment }+ \\
(1.5 \mathrm{l} / \mathrm{ha}) \text { crop spraying in } \\
\text { the tillering and early } \\
\text { booting phases }\end{array}$ & 17.1 & 33.7 \\
\hline $\begin{array}{c}\text { 7. Microfeed Extra } \\
\text { Phosphorus }(1.5 \mathrm{l} / \mathrm{t}) \text { seed } \\
\text { treatment }+(1.5 \mathrm{l} / \mathrm{ha}) \mathrm{crop} \\
\text { spraying in the tillering } \\
\text { and early booting phases }\end{array}$ & 17.4 & 32.6 \\
\hline
\end{tabular}

In the variants with the treatment of seeds and vegetative plants, the effect of the tested preparations increased: the number of productive stems by $13-17$ $\mathrm{pcs} / \mathrm{m} 2$, the water content of the ear by $1.2-1.6 \mathrm{pcs}$, the weight of 1000 grains by $2.0-2.3 \mathrm{~g}$, in comparison with the control.

Higher indicators of the yield structure in the variants using Humistim and microelement fertilizers of the MicroFeed brand provided an increase in the yield of spring wheat (Table 3). Thus, seed treatment with Humistim preparation $(5 \mathrm{l} / \mathrm{t})$ increased the yield of spring wheat by $0.23 \mathrm{t} / \mathrm{ha}$, with MicroFeed Complex and MicroFeed Extra Phosphorus (1.5 1/t) by 0.17-0.19 t/ha, with the yield in the control variant equal to $3.88 \mathrm{t} / \mathrm{ha}$.

Seed treatment and double crop treatment of spring wheat contributed to an increase in the yield of spring wheat compared to the control: in the variant using the biopreparation Humistim by $0.55 \mathrm{t} / \mathrm{ha}$, MicroFeed Complex by $0.53 \mathrm{t} / \mathrm{ha}$, MicroFeed Extra Phosphorus by $0.52 \mathrm{t} / \mathrm{ha}$.

Table 3. Effect of bio-fertilizer Humistim and microelement fertilizers of the MicroFeed brand on the yield of spring wheat, 2018-2020

\begin{tabular}{|c|c|c|}
\hline \multirow[b]{2}{*}{ Variants } & \multicolumn{2}{|c|}{ Yield, $\mathrm{t} / \mathrm{ha}$} \\
\hline & total & $\begin{array}{l}\text { Increase } \\
\text { relative } \\
\text { to the } \\
\text { control }\end{array}$ \\
\hline 1. Control (untreated) & 3.88 & - \\
\hline $\begin{array}{l}\text { 2. Humistim }(5 \mathrm{l} / \mathrm{t}) \text {, seed } \\
\text { treatment }\end{array}$ & 4.11 & 0.23 \\
\hline $\begin{array}{l}\text { 3. MicroFeed Complex }(1.5 \mathrm{l} / \mathrm{t}) \\
\text { seed treatment }\end{array}$ & 4.07 & 0.19 \\
\hline $\begin{array}{l}\text { 4. Microfeed Extra Phosphor } \\
(1.5 \mathrm{l} / \mathrm{t}) \text { seed treatment }\end{array}$ & 4.05 & 0.17 \\
\hline $\begin{array}{l}\text { 5. Humistim }(5 \mathrm{l} / \mathrm{t}) \text { of seed } \\
\text { treatment }+(1.5 \mathrm{l} / \mathrm{ha}) \mathrm{crop} \\
\text { spraying in the tillering and } \\
\text { early booting phases }\end{array}$ & 4.43 & 0,55 \\
\hline $\begin{array}{l}\text { 6. Microfeed Complex }(1.5 \mathrm{l} / \mathrm{t}) \\
\text { seed treatment }+(1.5 \mathrm{l} / \mathrm{ha}) \mathrm{crop} \\
\text { spraying in the tillering and } \\
\text { early booting phases }\end{array}$ & 4.41 & 0.53 \\
\hline $\begin{array}{l}\text { 7. Microfeed Extra Phosphorus } \\
(1.5 \mathrm{l} / \mathrm{t}) \text { seed treatment }+(1.5 \\
\text { 1/ha) crop spraying in the }\end{array}$ & 4.40 & 0.52 \\
\hline
\end{tabular}




\begin{tabular}{|c|l|l|}
\hline $\begin{array}{c}\text { tillering and early booting } \\
\text { phases }\end{array}$ & & \\
\hline $\mathrm{LSD}_{05}$ & 0.14 & \\
\hline
\end{tabular}

According to the results of the analysis of the quality indicators of grain, it was found that the preparations had a positive effect on the content of raw gluten in the grain, while the effectiveness of the preparations depended on the method and time of their application (Table 4).

In the variants with the treatment of seeds with preparations, the content of raw gluten in the grain of spring wheat was-19.8-19.9\% with the content of gluten in the control equal to $19.1 \%$. Seed treatment and double crop treatment in the tillering and early booting phases with the biological preparation Humistim increased the content of raw gluten in the grain by $2.1 \%$, and with microelement fertilizers MicroFeed Complex and Microfeed Extra Phosphorus by 1.7-1.9 \%.

The calculation of economic efficiency based on the results of the conducted studies showed that the use of bio-and microelement fertilizers increased the cost of gross production, and due to small rates of application at a low cost of the preparations, it was economically profitable.

Thus, seed treatment in combination with double treatment of crops with Humistim biofertilizer increased direct production costs-by 825 rubles/ha, but due to increased productivity, the cost of gross output increased - by $6,600 \mathrm{rubl}$./ha, conditional net income-by 5,775 rubl./ha, the cost of 1 ton of grain decreased-by 511.55 rubles. The efficiency of using fertilizers with microelements of MicroFeed Complex with similar methods of application was slightly lower: the value of conditional net income increased by $5,502 \mathrm{rubl} . / \mathrm{g}$, the level of profitability by $20 \%$, respectively. Treatment of seeds and crops with MicroFeed Extra Phosphorus fertilizer, although it provided an increase in yield $0.52 \mathrm{t} / \mathrm{ha}$, but due to the higher cost of the preparation (1000 rubl./l.), the value of the conditional net income with its use was minimal and amounted to $27,693.31 \mathrm{rubl} . / \mathrm{ha}$, with a profitability level of $110.3 \%$.

Table 4. Effect of biofertilizer Humistim and microelement fertilizers of the MicroFid brand on the quality of spring wheat grain, 2018-2020

\begin{tabular}{|c|c|c|}
\hline \multirow[b]{2}{*}{ Variants } & \multicolumn{2}{|c|}{ Gluten content, $\%$} \\
\hline & total & $\begin{array}{l}\text { increase } \\
\text { relative } \\
\text { to the } \\
\text { control }\end{array}$ \\
\hline 1. Control (untreated) & 19.1 & - \\
\hline $\begin{array}{l}\text { 2. Humistim }(51 / t) \text {, seed } \\
\text { treatment }\end{array}$ & 19.8 & 0.7 \\
\hline $\begin{array}{l}\text { 3. MicroFeed Complex (1.5 } \\
\text { 1/t) seed treatment }\end{array}$ & 19.9 & 0.8 \\
\hline $\begin{array}{l}\text { 4. Microfeed Extra } \\
\text { Phosphorus }(1.51 / \mathrm{t}) \text { seed } \\
\text { treatment }\end{array}$ & 19.8 & 0.7 \\
\hline $\begin{array}{l}5 . \text { Humistim }(5 \mathrm{l} / \mathrm{t}) \text { of seed } \\
\text { treatment }+(1.5 \mathrm{l} / \mathrm{ha}) \text { crop }\end{array}$ & 23.2 & 2.1 \\
\hline
\end{tabular}

\begin{tabular}{|c|c|c|}
\hline $\begin{array}{c}\text { spraying in the tillering and } \\
\text { early booting phases }\end{array}$ & & \\
\hline $\begin{array}{c}\text { 6. Microfeed Complex }(1.5 \\
\text { 1/t) seed treatment }+(1.5 \\
\text { 1/ha)crop spraying in the } \\
\text { tillering and early booting } \\
\text { phases }\end{array}$ & 21.0 & 1.9 \\
\hline $\begin{array}{c}\text { 7.Microfeed Extra } \\
\text { Phosphorus }(1.5 \mathrm{l} / \mathrm{t}) \text { seed } \\
\text { treatment }+(1.5 \mathrm{l} / \mathrm{ha}) \mathrm{crop} \\
\text { spraying in the tillering and } \\
\text { early booting phas }\end{array}$ & 20.8 & 1.7 \\
\hline LSD $_{05}$ & 0.6 & \\
\hline
\end{tabular}

\section{Conclusion}

Thus, it was found that the treatment of seeds with Humistim at a rate of $51 / t$, in combination with double crop treatment in the tillering and early phases at a rate of $5 \mathrm{l} / \mathrm{ha}$, increased the yield of spring wheat by $0.55 \mathrm{t} / \mathrm{ha}$, or $14.2 \%$, and the content of raw gluten in the grain by $2.1 \%$, in comparison with the control variant. The effectiveness of microelement fertilizers MicroFeed Complex and MicroFeed Extra Phosphorus in the treatment of seeds $(1.5 \mathrm{l} / \mathrm{t})$ and crops in the tillering and early booting phases $(1.5 \mathrm{l} / \mathrm{ha})$ was lower: the yield increase was $0.52-0.53 \mathrm{t} / \mathrm{ha}$, the content of raw gluten in the grain increased by 1.7-1.9 $\%$. The use of bio-and microelement fertilizers in spring wheat was economically profitable, increasing the cost of gross output by 6,240 to 6,600 rubles, the value of conditional net income by 2,940 to $5,775 \mathrm{rubl}$./ha, with a profitability level of 110.3 to $134.9 \%$.

\section{References}

1. V. V. Novokhatin, T. V. Shelomentseva, Bull. Russ. Acad. Agr. Sci., 4 (2014)

2. T. V. Rednikova.. Zemledelie, 3 (2019)

3. P. Dopierala, L. Kordas Biul. Inst. Hodowli Aklimatyz. Rosl. (Warszawa), 253 (2019)

4. L. V. Yushkevich, I. A. Korchagina, A.V. Lomanovsky, Zemledelie, 6 (2014)

5. A.V. Gostev. Zemledelie, 6 (2019)

6. A. I. Belenkov, A.V. Zelenov, B. O. Amantaev. Zemledelie, 1 (2014)

7. P. A. Chekmarev, S. V. Lukin, Zemledelie, 8 (2014)

8. V. I. Lazarev, Zh. N. Minchenko, A. Ya. Bashkatov. Theor. \& Appl. Ecol. 3 (2020)

9. V. I. Kiryushin, S. V. Kiryushin, Agrotechnologies, textbook. St.Petersbourgh, Lan, 2015)

10. I. I. Gureev, M. N. Zherdev, A. L. Breketov, Zemledelie, 8 (2016)

11. D. W. Franzena, M. V McMullenb, D. S Mossetc, Agron. J.ournal. 371-375 (2018)

12. V. V. Nemchenko, M. Yu. Tsypysheva. Bull. Altai State Agrar. Univ. 8 (2014) 
13. A. Kabata. Trace elements in soils and plants, 4th ed. London-N.Y.: CRC Press Tailor and Francis Group Boca Raton (2011)

14. R. V. Bell, B. Dell. The role of trace elements in the sustainable production of food, feed, fiber and bioenergy, Moscow: International Institute of Plant Nutrition (2017) 